\title{
Uczelnie badawcze: Geografia produkcji wiedzy w kon- tekście koncentracji zasobów i akumulacji prestiżu
}

Pod względem naukowym stajemy się dla świata - jako system, poszczególne instytucje i ich wydziały, dyscypliny naukowe oraz pojedynczy naukowcy - niemal przezroczyści. Nadeszła bowiem epoka widzialności wszystkich najważniejszych wymiarów funkcjonowania nauki. Międzynarodowa widzialność naszego systemu nauki - ale i widzialność systemów międzynarodowych dla nas - mają szansę wywrzeć duży wpływ na strategiczne kierunki przyszłych zmian w szkolnictwie wyższym. Pełna przezroczystość (a tym samym mierzalność) w nauce pojawiła się w Europie dwie dekady temu, głównie dzięki konsekwentnemu zbieraniu zagregowanych danych krajowych przez OECD i Eurostat, a następnie dzięki udostępnianiu zdezagregowanych danych dotyczących publikacji i cytowań przez Web of Science (dziś Clarivate Analytics) i Scopus. Kolejnym krokiem było wkroczenie danych bibliometrycznych do polityki naukowej, a zwłaszcza do krajowych procedur ewaluacji nauki - obok tradycyjnej oceny eksperckiej. Pojawiło się coraz silniejsze łączenie danych bibliometrycznych z finansowaniem instytucjonalnym przy różnym udziale elementów peer-review.

$\mathrm{Z}$ czasem przekonanie o wysokiej jakości dostępnych danych (przede wszystkim dotyczących osiągnięć naukowych) zrodziło rosnące zaufanie do międzynarodowych rankingów uniwersyteckich, na czele z rankingiem szanghajskim i rankingiem lejdejskim. Ich metodologia opiera się w przeważającej mierze na wskaźnikach produkcji naukowej, a nie opiniach (pracodawców czy studentów): w tym sensie są bardziej obiektywne od pozostałych i pokazują miejsce polskich uczelni w międzynarodowej hierarchii prestiżu naukowego. A prestiż, podobnie jak pół wieku temu, opiera się wyłącznie na mierzalnych, międzynarodowych osiągnięciach naukowych. 
Świat nauki akademickiej (tak krajowy, jak i międzynarodowy) stał się zatem w ostatniej dekadzie całkowicie mierzalny, a indywidualne, instytucjonalne i krajowe osiągnięcia w ramach prestiżowej produkcji naukowej stały się w pełni widzialne. Dla wszystkich, wszędzie; również dla nas. Nasze instytucje akademickie są systematycznie poddawane pomiarowi, choćby przez KEJN, a kadra akademicka - choćby przez NCN przy okazji starań o konkurencyjne środki na badania i przez CK przy okazji starań o awans naukowy. Nie da się uciec przed rosnącym, systematycznym pomiarem w żadnym systemie europejskim z bardzo prostego powodu: w Polsce, podobnie jak gdzie indziej, pula środków dostępnych indywidualnie (bezpośrednio przez NCN) i instytucjonalnie (pośrednio przez KEJN) jest mała, a pula naukowców i subdyscyplin naukowych stale rośnie. Ponadto w całej Europie rośnie presja publiczna - a za nią polityczna - na ocenę osiągnięć naukowych inaczej niż tylko przez tradycyjną ocenę innych naukowców: reżim peer review jest stopniowo podważany przez coraz silniejszy reżim bibliometrii ewaluacyjnej.

Dla uczelni badawczych (a więc takich, dla których badania naukowe, publikacje i przychody z badań odgrywają kluczową rolę i które koncentrują się na obu głównych misjach - kształceniu i badaniach - a nie tylko na pierwszej z nich, zob. Kwiek 2015) ważne są wszystkie poziomy pomiaru, przy czym pomiary globalne dotyczą wszystkich polskich wydziałów (dokładnie: dyscyplin uprawianych w ramach uczelni) i wszystkich instytucji. Dla uczelni badawczych ważne są ranking CWTS (lejdejski) i ranking ARWU (szanghajski), ponieważ to one opierają się na danych dotyczących mierzalnego dorobku naukowego, a nie na danych dotyczących trudno mierzalnego prestiżu uczelni wśród pracodawców czy absolwentów. I tak w ramach rankingu ARWU waga wskaźników jakości kadry, osiągnięć naukowych i osiągnięć naukowych per capita to w sumie 70\%: składają się na nią najwyżej globalnie cytowani naukowcy (20\%), artykuły opublikowane w Nature i Science (20\%), artykuły indeksowane w Science Citation Index-expanded i Social Science Citation Index (czyli w bazie Web of Science) (20\%) oraz liczba publikacji w przeliczeniu na zatrudnionego naukowca (10\%).

Dla uczelni o aspiracjach badawczych z międzynarodowej perspektywy porównawczej liczy się zatem tylko jedno: publikacje indeksowane w międzynarodowych bazach Web of Science i Scopus. Podobnie z perspektywy międzynarodowego prestiżu naszych uczelni ważne są tylko rankingi oparte o produkcję naukową, czyli indeksowane publikacje (i ich cytowania). Wieloaspektowy pomiar osiągnięć naukowców i zespołów badawczych wzmocnił zawsze silnie obecne w nauce procesy pionowej stratyfikacji: zawsze było wiadomo, że jedne zespoły badawcze są lepsze od innych, podobnie jak jedne uczelnie i wydziały są lepsze od innych.

Wraz z coraz dokładniej kalibrowanymi pomiarami wszystkie nasze międzynarodowe słabości zostały obnażone przez międzynarodowe rankingi uniwersyteckie 
koncentrujące się na osiągnięciach naukowych. Ale i w skali kraju ujawniło się wyraźne zróżnicowanie; ujawniają się też stopniowo słabości uczelni pierwszoligowych wobec dwóch uczelni krajowej superligi, czyli Uniwersytetu Warszawskiego i Uniwersytetu Jagiellońskiego.

Dane dotyczące najlepszych polskich uczelni - zwłaszcza te odnoszące się do przepływu środków na badania z NCN i zmian kategorii uzyskiwanych w KEJN - pokazują systematyczne różnicowanie się systemu nauki akademickiej. Jesteśmy coraz silniej podzieleni pionowo. Mechanizm wspierający zróżnicowanie pionowe jest stosunkowo prosty: to konkurencyjnie zdobywane środki na badania, najważniejsze dla starań o wejście do ligi uczelni badawczych.

Upraszczając skomplikowane mechanizmy dystrybucji prestiżu i powstawania cennych publikacji w nauce (zob. Kwiek 2019), środki na badania (zwłaszcza pochodzące z NCN i ERC) prowadzą bezpośrednio do nowych badań, a zatem nowych publikacji; badania w większości dyscyplin wymagają grantów, ale otrzymywanie grantów wymaga rosnącej liczby najlepszych publikacji w najlepszych czasopismach. W ten sposób koło się zamyka: bez najlepszych publikacji nie ma nowych grantów na badania, zatem nie ma nowych badań, a zatem nie ma kolejnych nowych publikacji i ich cytowań. Pojawia się tym samym instytucjonalna równia pochyła, która dotyczy zarówno poziomu zespołów badawczych (czyli malejący dopływ środków z NCN czy ERC) i poziomu wydziałów (czyli malejący dopływ środków na badania związanych z wynikami parametryzacji, a w przyszłości ewaluacji). W nowej ustawie w miejsce podstawowych jednostek organizacyjnych pojawiły się dyscypliny, a więc nowa ewaluacja będzie określać koncentrację lub dekoncentrację środków w ujęciu dyscyplinarnym, a nie administracyjnym. Co może, choć nie musi - w ramach autonomii przyznanej w ustawie - prowadzić do zmian wewnętrznej struktury organizacyjnej uczelni.

Upraszczając po raz kolejny, obowiązujący system każdorazowo zmieniających się benchmarków w ocenie osiągnięć naukowych (czyli systemu jednostek referencyjnych i jednostek wzorcowych wyznaczanych dotąd w KEJN) powoduje, że nawet szybki wzrost osiągnięć niewiele zmienia w sytuacji uczelni, wydziału czy dyscypliny w ramach uczelni, jeśli tylko inne uczelnie, wydziały czy dyscypliny w systemie rosną szybciej. Przy czym brany pod uwagę wzrost dotyczy wyłącznie osiągnięć liczących się dla NCN, KEJN, a w przyszłości KEN (w skali kraju) oraz dla rankingów globalnych: czyli publikacji indeksowanych w bazach Web of Science i Scopus, dodatkowo w ujęciu per capita. Premia prestiżowa i finansowa dla instytucji nie przychodzi zatem za sam wzrost liczby najlepszych publikacji - ale za wzrost szybszy od wzrostu konkurentów. Logikę konkurencji wprowadziła już poprzednia ustawa, obecna jedynie ją wzmacnia. 
Podobnie działa system obu wspomnianych rankingów międzynarodowych: osiągnięcia naszych uczelni oraz naszych dyscyplin w ramach uczelni są każdorazowo mierzone i porównywane z osiągnięciami innych uczelni i dyscyplin uprawianych w ich ramach (w skumulowanym ujęciu kilkuletnim). Utrzymanie kategorii w ramach nowej ewaluacji w coraz bardziej konkurencyjnych warunkach powinno teoretycznie kosztować coraz więcej naukowego wysiłku - kolejna ewaluacja (w 2021 roku) będzie trudnym sprawdzianem potencjału naukowego dla wszystkich polskich uczelni. W nowych warunkach (nowa klasyfikacja dyscyplin i wyjście poza dorobek wydziałów; międzynarodowa widzialność publikacji; liczba publikacji per capita ograniczona do 4 slotów publikacyjnych i publikacje przypisane do osoby) pojawi się nowa hierarchia instytucjonalnego prestiżu wsparta silnym finansowaniem lub jego brakiem. Czeka nas wiele niespodzianek, $w$ tym przede wszystkim prawdopodobne wyodrębnienie się superligi z pierwszej ligi polskich uczelni.

By odwołać się do wyników najnowszej parametryzacji: wyraźnie widać różnicę w potencjale naukowym między uniwersytetami, których jeden wydział ma kategorię A i dziesięć wydziałów posiada kategorię B (choćby Lublin, Rzeszów czy Zielona Góra) a Uniwersytetem Jagiellońskim, który ma wyłącznie wydziały z kategoriami A+ i A czy Uniwersytetem Warszawskim z pięcioma jednostkami z kategorią A+. Różnice w skali osiągnięć naukowych będą narastać wraz z każdym kolejnym etapem ewaluacji nauki.

Poznajemy coraz dokładniej geografię polskiej produkcji naukowej z międzynarodowej perspektywy porównawczej, więcej też możemy od swojego systemu nauki oczekiwać. Dane porównawcze pokazują, że świat polskiej akademii oddala się od świata uniwersytetów zachodnich w czterech istotnych kategoriach: prestiżowe publikacje (np. The Nature Index; highly cited researchers); prestiżowe granty międzynarodowe (np. z European Research Council); średnia indywidualna produktywność naukowa (np. dane według bazy Scopus, a zwłaszcza SciVal); struktura publikacji naukowych (np. Polska Bibliografia Naukowa); oraz - w efekcie powyższych - rankingi międzynarodowe oparte na międzynarodowo widzialnej, indeksowanej produkcji naukowej.

Rośnie dostępność danych bibliometrycznych: rolę wstępnego, dosyć surowego jeszcze filtra spełnia Polska Bibliografia Naukowa (PBN), według której na ponad milion $(1,004,102)$ publikacji polskich autorów (głównie z lat 2013-2017), tylko 207,632 (czyli jedynie 20,68\%) zostało opublikowanych na liście A czasopism, czyli w praktyce w czasopismach indeksowanych w bazie Web of Science, a w czasopismach z listy B, $\mathrm{C}$ i spoza listy zostało opublikowane niemal $40 \%$ wszystkich publikacji (odpowiednio $28,60 \%, 1,60 \%$ i 8,85\%). Jesteśmy także mistrzami w publikowaniu monografii: w analizowanym okresie wydaliśmy ich niemal 70 tysięcy $(67,891)$, czyli kilkanaście tysięcy rocznie. Oprócz tego udało nam się opublikować prawie 340,000 rozdziałów 
w pracach zbiorowych $(336,449)$. Nowa ewaluacja ma szansę zmienić dominującą dziś i nieprzystającą do standardów krajów wysokorozwiniętych strukturę produkcji naukowej poprzez nowe mechanizmy finansowe.

Publikacje i granty badawcze - wyznaczające docelowo strukturę przychodów badawczych i strukturę produkcji naukowej - w miejsce uzyskanych profesur i habilitacji to jedna z najbardziej doniosłych zmian, z których konsekwencji nie wszyscy jeszcze zdają sobie sprawę. Pierwszym krokiem jest zniesienie obowiązkowej habilitacji; kolejnym może być zniesienie profesury tytularnej i zastąpienie jej atrakcyjnym, trudno dostępnym i dobrze wynagradzanym stanowiskiem akademickim. Ważne jest jedno: rosnące (mierzalne i międzynarodowe) osiągnięcia naukowe oznaczają w nowym systemie potężne bodźce finansowe wzmacniające zwycięzców (zespoły badawcze, wydziały czy dyscypliny i wreszcie całe uczelnie) i osłabiające przegranych silniej niż kiedykolwiek wcześniej. Mechanizmy te działają w niewielkiej mierze już dzisiaj.

Spójrzmy przykładowo na dane dotyczące UAM i UW: prawie taka sama liczba studentów i kadry akademickiej, ale pięciokrotnie większy budżet UW na badania naukowe (w 2016 roku budżet UW wynosił $446 \mathrm{mln}$ zł, a UAM $92 \mathrm{mln}$ zł) i dwuipółkrotnie większy udział środków przeznaczanych na naukę w budżecie całkowitym (w 2016 roku udział ten sięga w przypadku UW 32,6\%, a UAM 13,1 \%). Jeśli w ramach logiki nowej ustawy najważniejsze na uczelniach badawczych (a z czasem flagowych) stają się badania naukowe (i przeznaczane na nie środki), to uczelnie superligi mogą oddalać się od uczelni pierwszej ligi w tempie przyspieszonym. Podobne procesy obrazują dane z NCN: UW i UJ w 2016 roku otrzymały wspólnie 23,71\% środków, UAM 5,03\%, a kilka pozostałych uczelni pierwszoligowych 2-4\%.

Zróżnicowanie pionowe w systemie trwa od momentu powstania NCN i to najlepszy mechanizm służący naturalnemu wyłanianiu instytucjonalnych liderów w nauce. Jednak jego skala pozostaje nadal zbyt mała z powodu stosunkowo niewielkich środków pozostających w gestii NCN (z których jedynie 71,23\% trafiło w 2016 roku do uczelni). Pomijam tutaj środki z European Research Council, które trafiają w ostatniej dekadzie niemal wyłącznie na UW.

W największym uproszczeniu: środki przeznaczane na badania przez superligę i pierwszą ligę polskich uczelni prowadzą do nowych, najczęściej dobrych publikacji (co wymusza konkurencyjna natura finansowania i sposób rozliczania grantobiorców NCN i ERC), ponadto w grantach zatrudniani są młodzi ludzie - doktoranci i postdocy. Rośnie zatem pula dobrych publikacji w instytucjach, które otrzymują konkurencyjne finansowanie. Efekt św. Mateusza - wzmacniający mocnych i osłabiający słabych - działa w tych instytucjach silniej niż w pozostałych, które tego konkurencyjnego finansowania na badania mają niewiele lub nie mają go wcale. Nowa ustawa mechanizmy te wzmacnia jednocześnie na kilku poziomach: finansowania 
statutowego, finansowania grantowego i (nowego) finansowania doskonałościowego poprzez konkurs na uczelnie badawcze.

Inna struktura przychodów w uczelniach (funkcjonalnie) bardziej badawczych pozostaje w sprzężeniu zwrotnym z inną strukturą produkcji naukowej. Dane PBN pokazują ewolucję tej drugiej struktury w czasie: na przykład na UW liczba artykulów z listy A wynosiła w ostatnich latach rocznie 1,500-1,800, na UJ (z Collegium Medium) 2,100-2,700, a na UAM ok. 800-1,100 (ale z Uniwersytetem Medycznym, gdyby rozważyć możliwą w nowej ustawie federalizację uczelni, liczba ta wzrasta do 1,600-2,100); podobnie rośnie ich liczba na Politechnice Warszawskiej (8501,200), AGH (1,200-1,800) oraz w trzech mniejszych ośrodkach (UMK - 850-1,000, Uniwersytet Wrocławski - 700-800 oraz Politechnika Gdańska - 450-610). Zmiany w czasie pokazują, że na przykład niewielki UMK dogania pod względem liczby najcenniejszych publikacji UAM, a ten po możliwym połączeniu z Uniwersytetem Medycznym w Poznaniu ma ich więcej niż UW. Jednocześnie w superlidze UW i UJ systematycznie w ostatnich latach spada liczba rozdziałów opublikowanych w pracach zbiorowych.

Nowa ustawa wprowadza silne mechanizmy różnicowania pionowego w systemie: pojawią się uczelnie badawcze, dodatkowo finansowane przez sześć lat w trybie konkursowym, z których kilka z czasem stanie się uczelniami flagowymi, chociaż o tym ustawa nie wspomina. Dla uczelni o aspiracjach badawczych to niezwykle istotna informacja, ponieważ pokazuje długoterminową logikę rozwoju systemu: rosnące funkcjonalne zróżnicowanie jego elementów i dodatkowe dofinansowanie nauki tam, gdzie istnieje jej największy potencjał. Wprowadzane mechanizmy ewaluacji prowadzą nie tylko do akumulacji przewag, ale w nieunikniony sposób również do akumulacji strat. Wystarczy wyliczyć poziom 10\% dodatkowych środków finansowych od małych i od dużych rocznych uczelnianych budżetów rok po roku, przez sześć lat, dla dziesięciu uczelni uczestniczących w konkursie. Procesy różnicowania systemu pozostają w pełnej zgodności z paradygmatem globalnym odniesionym do permanentnie niedofinansowanych systemów, niezdolnych do podtrzymywania dobrej nauki we wszystkich swoich elementach, który był mocnym założeniem propozycji mojego zespołu przygotowującego propozycję nowej ustawy (Kwiek i in. 2016).

Zastosowanie w praktyce mechanizmu finansowego wspierającego w nowej ustawie rozwój uczelni badawczych oznacza proces kumulacji zasobów i prestiżu w najlepszych krajowych ośrodkach naukowych, a dokładnie tego jak dotąd najbardziej brakowało. Proces ten trwa w lagodnej formie od dekady; wzmocniło go powstanie NCN na poziomie indywidualnym oraz powstanie KEJN na poziomie instytucjonalnym. Mechanizmy, którymi posługują się NCN (z pomocą wspólnoty naukowej), KEJN (z pomocą polskiej wspólnoty eksperckiej) i nowy program doskonałościowy zaproponowany w ustawie (z pomocą międzynarodowej wspólnoty eksperckiej) będą 
się wzajemnie wzmacniać: każdy z nich wspiera finansowo naukę w powszechnie w świecie rozumianym sensie najlepszych publikacji i pozwala stopniowo przestać finansować naukę słabą, czyli taką, która w naukach podstawowych nie prowadzi do najlepszych publikacji. Idea konkurencji w nauce (tradycyjnie: w naukach podstawowych uprawianych w sektorze uniwersyteckim) w ostatnich dziesięcioleciach była w Polsce niemal nieobecna; wraz z nową ustawą powraca w silnej wersji, zastosowana do wszystkich poziomów funkcjonowania systemu.

prof. zw. dr hab. Marek Kwiek

\section{Literatura}

Kwiek, M. (2015). Uniwersytet $w$ dobie przemian: Instytucje i kadra akademicka $w$ warunkach rosnacej konkurencji. Warszawa: Wydawnictwo Naukowe PWN.

Kwiek, M. (2018). Ustawa 2.0 a mierzalność i porównywalność osiągnięć naukowych. Nauka. 1: 65-86.

Kwiek, M. (2019). Changing European Academics: A Comparative Study of Social Stratification, Work Patterns and Research Productivity. London-New York: Routledge.

Kwiek, M., Antonowicz, D., Brdulak, J., Hulicka, M., Jędrzejewski, T., Kowalski, R., Kulczycki, E., Szadkowski, K., Szot, A. i Wolszczak-Derlacz, J. (2016). Projekt założeń do ustawy Prawo o szkolnictwie wyższym. Poznań: Uniwersytet im. Adama Mickiewicza.

CYTOWANIE: Kwiek, M. (2018). Uczelnie badawcze: Geografia produkcji wiedzy w kontekście koncentracji zasobów i akumulacji prestiżu. Nauka i Szkolnictwo Wyższe. 1(51): 7-14. DOI: 10.14746/nisw.2018.1.0.

MAREK KWIEK - prof. dr hab., dyrektor Centrum Studiów nad Polityką Publiczną i kierownik Katedry UNESCO Badań Instytucjonalnych i Polityki Szkolnictwa Wyższego UAM w Poznaniu. Od piętnastu lat prowadzi rozległe międzynarodowe badania szkolnictwa wyższego. Międzynarodowy doradca w sprawach polityki szkolnictwa wyższego (OECD, KE, Rada Europy, OBWE, USAID, UNDP i Bank Światowy). Kierownik lub partner w 50 międzynarodowych projektach badawczych i doradczych. Publikuje przede wszystkim w obiegu międzynarodowym, m.in. w Science and Public Policy, Comparative Education Review, Higher Education czy Studies in Higher Education. Autor 180 artykułów, ostatnie monografie to: Changing European Academics: A Comparative Study of Social Stratification, Work Patterns and Research Productivity (2019), Uniwersytet $w$ dobie przemian: Instytucje i kadra akademicka w warunkach rosnacej konkurencji (2015), Knowledge Production in European Universities: States, Markets, and Academic Entrepreneurialism (2013) i Transformacje uniwersytetu: Zmiany instytucjonalne i ewolucje polityki edukacyjnej w Europie 
(2010). Członek rad redakcyjnych prestiżowych czasopism międzynarodowych: Higher Education Quarterly, European Educational Research Journal, British Educational Research Journal i European Journal of Higher Education. W latach 2012-2017 kierował projektem MAESTRO (NCN): Program Międzynarodowych Badań Porównawczych Szkolnictwa Wyższego, a w 2015 roku otrzymał subsydium profesorskie w programie MISTRZ (FNP).

E-mail:kwiekm@amu.edu.pl. 